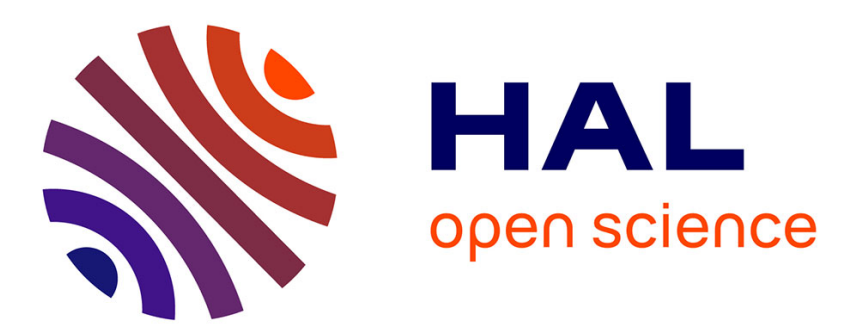

\title{
River bed-load sediments and suspended particles: two different worlds for trace metals
}

Anaëlle Simonneau, Lauriane Ledieu, Olivier Cerdan, Marielle Hatton, Valérie Laperche, Lydie Le Forestier, Fatima Laggoun-Défarge

\section{- To cite this version:}

Anaëlle Simonneau, Lauriane Ledieu, Olivier Cerdan, Marielle Hatton, Valérie Laperche, et al.. River bed-load sediments and suspended particles: two different worlds for trace metals. EGU General Assembly 2020, May 2020, Online, France. 10.5194/egusphere-egu2020-19850 . hal-03554405

\author{
HAL Id: hal-03554405 \\ https://hal.science/hal-03554405
}

Submitted on 4 Feb 2022

HAL is a multi-disciplinary open access archive for the deposit and dissemination of scientific research documents, whether they are published or not. The documents may come from teaching and research institutions in France or abroad, or from public or private research centers.
L'archive ouverte pluridisciplinaire HAL, est destinée au dépôt et à la diffusion de documents scientifiques de niveau recherche, publiés ou non, émanant des établissements d'enseignement et de recherche français ou étrangers, des laboratoires publics ou privés. 


\title{
EGU2020-19850
}

https://doi.org/10.5194/egusphere-egu2020-19850

EGU General Assembly 2020

(c) Author(s) 2022. This work is distributed under

the Creative Commons Attribution 4.0 License.

\section{River bed-load sediments and suspended particles: two different worlds for trace metals}

\author{
Anaëlle Simonneau ${ }^{1}$, Lauriane Ledieu ${ }^{1}$, Olivier Cerdan ${ }^{2}$, Marielle Hatton ${ }^{1}$, Valérie Laperche ${ }^{2}$, Lydie \\ Le Forestier $^{1}$, and Fatima Laggoun ${ }^{1}$ \\ 1Univ. Orléans, CNRS, BRGM, ISTO, UMR 7327, F-45071, Orléans, France (anaelle.simonneau@univ-orleans.fr) \\ ${ }^{2}$ BRGM, 3 avenue Claude Guillemin, 45060 Orléans, France
}

Anthropogenic activities release many types of contaminants, such as trace metals, in the environment. For recent decades, numerous studies investigated their behavior, particularly in the dissolved phase. The transfer of contaminants adsorbed on the particulate phase received less attention although particulate matter also plays a key role in their propagation. One first difficulty is the variability of adsorption and releasing processes driven by both water physico-chemical conditions and contaminants properties. Secondly, there are different compartments in particulate phases, e.g. bed-load sediments and suspended particles, and the proportion of these two worlds is highly variable according to climate conditions (temperature, rainfall) and stream (hydro)geomorphological characteristics. In this context, our study investigates trace metal dynamics ( $\mathrm{Pb}, \mathrm{Zn}, \mathrm{Cu}$ ) in bed-load sediments and suspended particles from a small tributary of the Loire River, the Egoutier stream (Loiret, France). High spatial and temporal sampling frequency of the two fractions allowed to understand the patterns of trace metals transfer. Trends of trace metals contents observed in the particulate phase correspond to those in the dissolved one, except for $\mathrm{Pb}$, the most insoluble compound. Contaminants concentrations and behaviors are driven both by trace metals order of solubility in bed-load sediments and suspended particles, and by external factors such as meteorological conditions, stream geochemistry and geomorphology. Besides, they are mostly adsorbed on iron and manganese oxides from suspended particles and on organic compounds from the bed-load sediments. Their temporal dynamics are controlled by seasons variabilities, notably rain amounts and humid periods, whereas their spatial distribution essentially reflects stream geomorphology, notably by the presence of a small pond creating a disconnection between the upstream and the downstream part of the watercourse and therefore two different patterns of transfert. Upstream, bed-load sediments contamination presents large fluctuations regulated by anthropogenic releases during dry periods and organic supplies during the humid ones, whereas homogeneous levels were observed downstream. In the suspended particles fraction, upstream higher contents are only correlated to humid periods, where more oxides are transported, while downstream transport is amplified by higher rain amounts. 